\title{
Efektivitas Pengelolaan Keuangan Desa Di Desa Sijungkang Kecamatan Angkola Timur Kabupaten Tapanuli Selatan
}

\author{
Iska Amelia Harahap \\ Fakultas Dakwah dan Ilmu Komunikasi IAIN Padangsidimpuan \\ (iskaamelia@gmail.com)
}

\begin{abstract}
The problem in this study is that the development in Sijungkang Village is not in accordance with village funds given to the village government, where the existing development in the village is of poor quality such as footpaths and water ropes. With village funds, the amount of development in the village should be of high quality and durable, but the reality of the village development is that there are several buildings that have been damaged for a year, such as footpaths and water ropes. The formulation of the problem in this study is, "how to use village funds as infrastructure in Sijungkang Village, Angkola Timur District, South Tapanuli Regency and what are the supporting and inhibiting factors in Village Financial Management as Community Empowerment in Sijungkang Village, Angkola Timur District, South Tapanuli District. This type of research is qualitative research using descriptive methods that aim to give a clear picture of a phenomenon or social reality relating to the problem under study. The results of this study indicate that the effectiveness of village financial management as community empowerment in the village of Sijungkang, Angkola Timur District, South Tapanuli Regency has not been effective, because it is seen from the indicators that it is transparent, accountable, participatory and orderly and budgetary discipline. Among the four indicators above which are less effective, there is no transparency from the manager. So that the people did not know how much village funds were received and intended.
\end{abstract}

Keywords: Effectiveness, Financial Management, Village Funds.

Abstrak

Permasalahan dalam penelitian ini bahwa pembangunan yang ada di Desa Sijungkang tidak sesuai dengan dana desa yang diberikan kepada pemerintah desa, dimana pembangunan yang ada di desa tersebut kualitasnya kurang bagus seperti jalan setapak, dan tali air. Mestinya dengan dana desa sebesar itu pembangunan yang ada di desa tersebut seharusnya berkualitas dan tahan lama tetapi realitanya pembangunan desa tersebut ada beberapa bangunan yang baru setahun sudah mengalami kerusakan seperti jalan setapak dan tali air. Rumusan masalah dalam penelitian ini adalah, "bagaimana penggunaan dana desa sebagai infrastruktur di Desa Sijungkang Kecamatan Angkola Timur Kabupaten Tapanuli Selatan dan Apa saja faktor-faktor pendukung dan penghambat dalam Pengelolaan Keuangan Desa sebagai Pemberdayaan masyarakat di Desa Sijungkang Kecamatan Angkola Timur Kabubaten Tapanuli Selatan. Jenis penelitian ini adalah penelitian kualitatif dengan menggunakan metode deskriptif yang 
bertujuan memberi gambaran secara jelas suatu fenomena atau kenyataan sosial yang berkenaan dengan masalah yang diteliti. Hasil penelitian ini menunjukkan bahwa efektivitas pengelolaan keuangan desa sebagai pemberdayaan masyarakat di desa Sijungkang Kecamatan Angkola Timur Kabupaten Tapanuli Selatan belum efektif, karena dilihat dari indikatorya itu transparan, akuntabel, partisipatif dan tertib dan disiplin anggaran. Diantara keempat indikator di atas yang kurang efektif yaitu tidak ada tranparansi dari pihak pengelola. Sehingga masyarakat tidak mengetahui berapa dana desa yang diterima dan diperuntukkannya.

Kata Kunci : Efektivitas, Pengelolaan Keuangan, Dana Desa

\section{A. Pendahuluan}

Menurut Undang-Undang Nomor 23 Tahun 2014 Tentang Pemerintah Daerah, Desa adalah kesatuan masyarakat hukum yang memiliki batas wilayah yang berwenang untuk mengatur dan mengurus urusan pemerintah, kepentingan masyarakat setempat berdasarkan prakarsa masyarakat, hak-hak asal usul atau hak tradisional yang diakui dan dihormati setiap pemerintahan Negara kesatuan Republik Indonesia. Secara administrasi desa merupakan bentuk pemerintahan terkecil yang dipimpin oleh Kepala Desa dari pemilihan Rakyat secara langsung melalui pemilihan Kepala Desa atau biasa disebut Pilkades. Dalam menjalankan suatu pemerintahan di desa Kepala Desa dibantu oleh staf-staf desa. Staf-staf desa ini menjalankan pekerjaannya sesuai dengan jabatan masing-masing, antara lain: Sekretaris Desa, Kepala Urusan Umum, Kepala Urusan Pembangunan, Kepala Urusan Keuangan, Kepala Urusan Pemerintahan, Kepala Urusan Kesejahteraan Rakyat dan Kepala Dusun.

Anggaran Pendapatan dan Belanja Desa (APBDesa) merupakan penjabaran kebutuhan daerah dalam membangun desa sebagaimana diatur dalam Peraturan Menteri Dalam Negeri Nomor 37 tentang Pedoman Pengelolaan Keuangan Desa. Pemanfaatan Alokasi Dana Desa (ADD) sebagaiamna termuat dalam APBD perlu ditindaklanjuti oleh pemerintah desa dan dibantu oleh potensi dan swadaya desa setempat. Hal ini tidak lain adalah bagaimana pemerintah daerah memberikan kewenangan kepada pemerintah desa untuk lebih kreatif dalam menjawab kebutuhan masyarakatnya.

Kegiatan Anggaran Pendapatan dan Belanja Daerah merupakan wujud dari komitmen seluruh jajaran pemerintah dalam mewujudkan pemerintah yang transparan, responsif dan akuntabel pada berbagai aspek dalam tugas pemerintahan umum, pelayanan masyarakat dan pembangunan sampai kepelosok desa sebagaimana diamanatkan dalam paket undang-undang tentang pemerintahan daerah dan keuangan yaitu Undang-undang nomor 17 tahun 2003 tentang keuangan Negara dan Undangundang nomor 32 tahun 2004 tentang Pemerintah Daerah serta Undang- Undang nomor 15 tahun 2004 tentang Pemeriksaan Pengelolaan dan Tanggung Jawab Keuangan Negara. Paket perundang-undangan ini kemudian ditinjaklanjuti dengan ditetapkannya Peraturan Pemerintah nomor 58 tahun 2005 tentang Pengelolaan Keuangan Daerah, Peraturan Pemerintah nomor 72 tahun 2005 tentang Desa, Peraturan Menteri Dalam Negeri nomor 13 tahun 2006 sebagaimana telah diubah beberapa kali .

Pemerintah berusaha mengatur, mengurus urusan pemerintahan dan kepentingan masyarakat setempat tentunya diperlukan pendapatan agar dapat tercapai tujuan dalam pembangunan dan kesejahteraan desa salah satu sumber pendapatan desa berfungsi 
sebagai sumber operasional desa dan untuk pemberdayaan masyarakat adalah Alokasi Dana Desa atau disebut juga dengan dan ADD.

Menurut Undang-Undang Nomor 6 Tahun 2014 Tentang Desa, alokasi dana desa paling sedikit $10 \%$ (sepuluh perseratus) dari dana perimbangan yang diterima Kabupaten / Kota dalam Anggran Pendapatan dan Belanja Daerah setelah dikurangi dana alokasi khusus. Penggunaan anggaran alokasi dana desa adalah sebesar 30\% (tiga puluh perseratus) untuk belanja aparatur dan operasional pemerinthan desa, sebesar $70 \%$ (tujuh puluh perseratus) untuk biaya pemberdayaan masyarakat. Dengan diterimanya dana bagi desa tersebut, pemerntahan desa harus siap dan mampu dalam mengelola dana desa berdasarkan asas transparan, akuntabel, partisipasif serta dilakukan dengan tertib dan disiplin anggaran sesuai dengan Permendagri No. 37 tahun 2007 tentang Pedoman Pengelolaan Dana Desa.

Keuangan desa tersebut dikelola melalui kegiatan yang meliputi perencanaan, penganggaran, penausahaan, pelaporan, pertanggung jawaban dan pengawasan keuangan desa yang dilakukan oleh Kepala Desa yang dibantu oleh Pelaksana Teknis Pengelolaan Keuangan Desa (PTPKD). Dalam tahapa perencanaan, kepala Desa menyusun rancangan pembangunan jangka menengah desa (RPJMD) dan rencana kerja pembangunan desa (RKPDesa). kemudian pemerintah Kabupaten / Kota dana tersebut dianggarkan dan direalisasikan untuk prmbangunan desa yang merupakan program inti dari desa. Sebelum adanya pembangunan, badan permusyawaratan desa (BPD) dan pemerintah desa juga melibatkan unsure masyarakat desa untuk memusyawarakan hal hal yang mengenai program desa.

Kegiatan musyawarah dilaksanakan paling kurang sekali dalam setahun dan biasa dinamakan dengan Musrembangdes (Musyawarah Rencana Pembangunan Desa). Pelibatan unsur masyarakat desa terdiri dari Kepala Desa, Perangkat Desa, dan perwakilan masyarakat. Hasil musyawarah yang dilakukan merupakan segala aspirasi, karena program desa berasal dari aspirasi masyarakat, dan kebutuhan masyarakat, selain itu dengan adanya partisipasi dari masyarakat maka akan mencegah akan timbulnya pertentangan dan konflik antara masyarakat dengan pemerintahan desa. Hal tersebut bersesuaian dengan nilai-nilai pemberdayaan yang terdapat dalam QS. Ar-Rad'du/13: 11

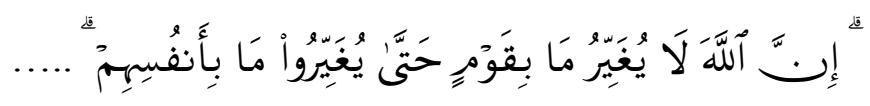

Artinya:

....Sesungguhnya Allah tidak merubah keadaan suatu kaum sehingga mereka mengubah keadaan yang ada pada diri mereka sendiri ...

Partisipasi masyarakat merupakan kunci dari pemberdayaan masyarakat, kemandirian dan kesejahteraan masyarakat. Pengembangan masyarakat merupakan wujud dari implementasi dakwah bil hal. Kata pengembangan masyarakat berorientasi pada perbaikan struktur-struktur sosial yang ada pada masyarakat untuk mengkoordinasikan seluruh kehidupan sosial dalam upaya pemenuhan kebutuhan. Struktur sosial yang selama ini memihak kepentingan kaum hartawan dan penguasa, dan merugikan rakyat lemah. Sistem yang selama ini menimbulkan ketertindasan rakyat miskin. ${ }^{1}$ Pemerintah desa juga berusaha untuk menunjukkan transparasi dan akuntabilitasnya kepada masyarakat untuk melakukan pengelolaan keuangan desa yang

1 Icol Dianto, "PERANAN DAKWAH DALAM PROSES PENGEMBANGAN MASYARAKAT ISLAM," Jurnal Hikmah 12, no. 1 (2018), hlm. 93. 
baik dan benar sesuai dengan Peraturan Menteri dalam Negeri No. 37 mengenai pedoman pengelolaan keuangan desa.

Anggaran Dana Desa yang diterima di Desa Sijungkang pada tahun 2017 sebesar Rp.800 juta dan Dana Desa ini dialokasikan pada pembangunan diantaranya : pembangunan jalan setapak atau rabat beton, pergudangan, tali air. Pembangunan ini berjalan dengan baik dan efektif tetapi dilihat dari segi pembangunannya tidak sesuai dengan Anggaran yang diterima oleh Desa.

Dengan bergulirnya dana-dana perimbangan melalui ADD harus menjadikan desa benar-benar sejahtera. Apabila melihat jumlah anggaran yang diberikan kepada Desa melalui Alokasi Dana Desa mencapai Rp.800 juta per Desa untuk Kabupaten Tapanuli Selatan, maka muncul pertanyaan apakah desa beserta elemen yang sudah mampu melaksanakan pengelolaan anggaran tersebut secara baik. Karena, dana yang diberikan tiap desa itu jumlahnya lumayan besar baik dalam mengembangkan pembangunan fisik dan non fisik.

Berdasarkan pengamatan awal peneliti, bahwa pembangunan yang ada di Desa Sijungkang tidak sesuai dengan dana desa yang diberikan kepada pemerintah desa, dimana pembangunan yang ada di desa tersebut kualitasnya kurang bagus seperti jalan setapak, dan tali air. Mestinya dengan dana desa sebesar itu pembangunan yang ada didesa tersebut seharusnya berkualitas dan tahan lama tetapi realitanya pembangunan desa tersebut ada beberapa bangunan yang baru setahun sudah mengalami kerusakan seperti jalan setapak dan tali air.

\section{B. Landasan Teoritis}

\section{Pengertian Efektivitas}

Dalam kamus ilmiah populer efektivitas berasal dari kata "efektif" berarti ada efeknya, manjur, mujarab, mapan ${ }^{2}$. Efektifitas berasal dari bahasa Inggris yaitu efective yang berarti berhasil tepat atau mujur. Efektifitas adalah hubungan antara output dan tujuan. Dalam artian efektivitas merupakan ukuran seberapa jauh tingkat ouput, kebijakan dan prosedur dari organisasi mencapai tujuan yang ditetapkan. Jadi dapat dikatakan bahwa sebuah kegiatan tersebut adalah efektif apabila tujuan kegiatan itu akhirnya dapat dicapai. Tetapi bila akibat-akibat yang tidak dicari dari kegiatan mempunyai nilai yang lebih penting dibandingkan dari hasil yang dicapai sehingga mengakibatkan ketidakpuasan, meskipun efektif kegiatan tersebut dapat dikatakan tidak efesien. Pada dasarnya pengertian efektivitas yang umum menunjukkan pada taraf tercapainya hal, sering atau senantiasa dikaitkan dengan pengertian efesien, meskipun sebenarnya ada perbedaan diantara keduanya. Efektivitas menekankan pada hasil yang dicapai, sedangkan efesiensi lebih pada bagaimana cara mencapai hasil yang di capai membangdingkan antara input dan outputnya.

Terdapat tiga 3 perspektif yang utama didalam menganalisis apa yang disebut efektifitas organisasi yaitu :

a. Persepektif optimalisasi tujuan, yaitu efektifitas dinilai menurut ukuran seberapa jauh suatu organisasi berhasil mencapai tujuan yang layak dicapai. Pemusatan perhatian pada tujuan yang layak dicapai secara optimal, memungkinkan dikenalinya secara jelas bermacam-macam tujuan yang sering saling bertentangan, sekaligus dapat diketahui beberapa hambatan dalam usaha mencapai tujuan.

${ }^{2}$ Syarul Ramadhan, Kamus IImiah Popular, (Surabaya: Khanzanah Media IImu, 2010), hlm. 97. 
b. Persepektif sistem, yaitu efektivitas organisasi dipandang dari keterpaduan berbagai faktor yang berhubungan mengikuti pola, input, konversi, output dan umpan balik, dan mengikutsertakan lingkungan sebagai factor eksternal.

c. Persepektif perilaku manusia, yaitu konsep efektivitas organisasi ditekankan pada perilaku orang-orang dalam organisasi yang mempengaruhi keberhasian organisasi untuk periode jangka panjang. Disini dilakukan pengintegrasian antara tingkah laku individu maupun kelompok sebagai unit analisis, dengan asumsi bahwa cara satu-satunya mencapai tujuan adalah melalui tingkah laku orang-orang yang ada dalam organisasi tersebut. ${ }^{3}$ Jadi efektivitas merupakan kunci kesuksesasan suatu organisasi ${ }^{4}$

Efektivitas dapat dipandang sebagai suatu sebab oleh variabel-variabel lain. Efektivitas individu terdiri dari beberapa antara lain sebagai berikut:

a. Kemampuan,

b. Keterampilan,

c. Pengetahuna,

d. Sikap,

e. Motivasi dan stress

Efektifitas kelompok terdiri dari

a. Keterpaduan,

b. Kepemmimpinan,

c. Struktur,

d. Status,

e. Peran,

f. Norma-norma

Untuk efektifitas organisasi terdiri dari

a. Lingkungan

Lingkungan adalah tempat berlangsungnya bermacam-macam interaksi sosial antara berbagai kelompok.

b. Teknologi

Teknologi merupakan segala sesuatunya yang bisa diciptakan dan juga dibuat oleh seorang atau sekelompok manusia yang kemudian bisa memberikan nilai dan manfaat bagi sesama.

c. Pilihan strategi

Pilihan strategi merupakan cara atau proses yang digunakan untuk tercapainya sebuah tujuan.

d. Struktur

Struktur adalah tatanan atau susunan sosial yang membentuk beberapa kelompok sosial dalam suatu masyarakat.

e. Proses

Proses adalah serangkaian langkah sistematis, atau tahapan yang jelas dan dapat dilakukan berulang kali, untuk mencapai hasil yang diinginkan.

f. Kultur

Kultur adalah sesuatu yang berhubungan dengan kebudayaan.

${ }^{3}$ Ibnu Hasan Muchtar dan Farhan Muntafa, Efektivitas FKUB Dalam Pemeliharaan Kerukunan Umat Beragama, (Jakarta: Puslitbang Kehidupan Keagamaan, 2015), hlm. 6-8. 106.

${ }^{4}$ Wibowo, Manajemen Kinerja, (Jakarta: PT Persada Granfindo Persada, 2012), hlm. 
Efektifitas setiap organisasi sangat dipengaruhi oleh perilaku manusia, karena merupakan sumber daya yang umum bagi semua organisasi.Kinerja organisasi tergantung dari kinerja individu, dan manejer/pimpinan harus mempunyai kemampuan lebih dari sekedar pengetahuan dalam hal penentuan kinerja individu.

\section{Pengertian Pengelolaan}

Pengelolaan merupakan terjemahan dari kata "management", terbawa oleh derasnya arus penambahan kata pungut ke dalam bahasa Indonesia, istilah Inggris tersebut lalu di Indonesia menjadi manajemen. Manajemen berasal dari kata to manage yang artinya mengatur, pengaturan dilakukan melalui proses dan diatur berdasarkan urutan dari fungsi-fungsi manajemen. Jadi manajemen itu mrupakan suatu proses untuk mewujudkan tujuan yang diinginkan melalui aspek-aspeknya antara lain planning, organizing, octuating, dan controlling.

Dalam kamus bahasa Indonesia lengkap disebutkan bahwa pengelolaan adalah proses atau cara pembuatan mengelola atau proses melakukan kegiatan tertentu dengan menggerakkan tenaga orang lain, proses yang membantu merumuskan kebijaksanaan dan tujuan organisasi tau proses yang memberikan pengawasan pada semua hal yang terlibat dalam pelaksanaan kebijaksanaan dan pencapai tujuan. ${ }^{5}$

Menurut Suharsimi arikunta pengelolaan adalah subtantifa dari mengelola, sedangkan mengelola berarti suatu tindakan yang dimulai dari penyusunan data, merencana, mengorganisasikan, melaksanakan, sampai dengan pengawasan dan penilaian. Dijelaskan pengelolaan menghasilkan suatu dan sesuatu itu dapat merupakan sumber penyempurnaan dan peningkatan pengelolaan selanjutnya.

Marry Parker Follet mendefinisikan pengelolaan adalah seni atau proses dalam menyelesaikan sesuatu tersebut, terdapat tiga faktor yang terlibat

a. Adanya penggunaan sumber daya organisasi, baik sumber daya manusia maupun faktor-faktor produksi lainnya.

b. Proses yang bertahap mulai dari perencanaan, pengorganisasian, pengarahan dan pengimplementasian, hingga pengendalian dsn pengawasan.

c. Adanya seni dalam penyelesaian pekerjaan. ${ }^{6}$

M. Manulang dalam bukunya dasar-dasar managemen istilah pengelolaan (managemen) mengandung tiga pengertian yaitu : pertama, managemen sebagai suatu proses, kedua, manajemen sebagai kolektifitas orang-orang yang melakukan aktifitas manajemen dan yang ketiga, manajemen sebagai suatu seni dan sebagai suatu ilmu. Menurut pengertian yang pertama yakni manajemen sebagai suatu proses, dalam buku encyclopedia of the social sciences dikatakan bahwa manajemen adalah suatu proses dengan proses mana pelaksanaan suatu tujuan tertentu diselenggarakan dan diawasi. Menurut pengertian yang kedua, manajemen adalah kolektifitas orang-orang yang melakukan aktivitas manajemen. Menurut pengertian yang ketiga, manajemen adalah suatu seni atau ilmu adalah seni dan ilmu perencanaan, pengorganisasian, penyusunan, pengarahan, dan pengawasan dari pada sumber daya manusia untuk mencapai tujuan yang sudah ditetapakan terlebih dahulu. ${ }^{7}$

${ }^{5}$ Daryanto, Kamus Indonesia Lengkap, (Surabaya: Apolo, 1997), hlm. 348.

${ }^{6}$ Erni Tisnawati Sule, Kurniawan Saefulah, Pengantar Manajemen, (Jakarta: Kencana Perdana Goup, 2009), hlm. 6.

${ }^{7}$ M. Manulang, Dasar-Dasar Manajemen, (Jakarta: Ghalia Indonesia, 1990), hlm 17-19. 
Jadi dapat disimpulkan bahwa pengelolaan (manajemen) adalah suatu cara atau proses yang dimulai dari perencanaan, pengorganisasian, pengawasan, dan evaluasi untuk mencapai suatu tujuan yang telah ditentukan agar berjalan efektif dan efisien.

\section{Fungsi-Fungsi Pengelolaan}

Banyak sekali fungsi manajemen, tapi dapat ditarik kesimpulan dari pendapat para ahli ada empat fungsi yang sama yakni perencanaan, pengorganisasian, pengarahan, dan pengawasan. ${ }^{8}$

a. Perencanaan

Perencanaan merupakan pemilihan dan penghubung fakta menguatkan asumsiasumsi tentang masa depan dalam membuat visualisasi dan perumusan kegiatan yang diusulkan dan memang diperlukan untuk mencapai hasil yang diinginkan. Perencanaan mencakup kegiatan pengambilan keputusan, karena termasuk pemilihan alternatifalternatif kepuasan. Diperlukan kemampuan untuk mengadakan visualitas dan melihat kedepan guna merumuskan suatu pola dari himpunan tindakan untuk masa mendatang.

b. Pengorganisasian

Sp. Siagian mendefinisikan bahwa pengorganisasian adalah keseluruhan proses pengelompokan orang-orang, alat-alat, tugas-tugas tanggung jawab dan wewenang sedemikian rupa sehingga tercipta suatu organisasi yang dapat digerakkan sebagai suatu kesatuan dalam rangka pencapaian tujuan yang telah ditetapkan.

c. Pengerakan

Penggerakan atau juga biasa didefenisikan sebagai segala tindakan untuk menggerakkan orang-orang dalam suatu organisasi, agar dengan kemauan dengan penuh berusaha mencapai tujuan organisasi dengan berlandaskan pada perencanaan. Penggerakan mencakup penetapan dan perumusan kebutuhan manusiawi dari pegawaipegawainya, memberi penghargaan, memimpin mengembangkan dan memberi kompensasi kepada mereka, aktuating atau juga disebut gerakan aksi mencakup kegiatan yang dilakukan seorang menejer untuk mengawali dan melanjutkan kegiatan yang ditetapkan oleh unsur-unsur perencanaan dan pengorganisasian agar tujuan-tujuan dapat tercapai.

d. Pengawasan

Pengawasan merupakan pemeriksaaan apakah semua yang terjadi sesuai dengan rencana yang ditetapkan, intruksi yang dikeluarkan sesuai dengan prinsip yang telah ditetapkan. ${ }^{9}$ Prinsip-prinsip pengawasan; a) dapat merefleksikan sifat-sifat dan kebutuhan-kebutuhan dari kegiatana-kegiatan yang harus diawasi, b) dapat dengan segera melaporkan penyimpangan-penyimpangan, c) fleksibel, d) dapat merefleksi pola organisasi, e) ekonomis, f) dapat dimengerti, dan g) dapat menjamin diadakannya tindakan korektif.

\section{Keuangan Desa}

Keuangan Desa adalah semua hak dan kewajiban Desa yang dapat dinilai dengan uang serta segala sesuatu berupa uang dan barang yang berhubungan dengan pelaksanaaan hak dan kewajiban Desa. ${ }^{10}$ Dana desa dikelola berdasarkan azas-azas

\footnotetext{
${ }^{8}$ Hendra Karianga, Partisipasi Masyarakat Dalam Pengelolahan Daerah, (Bandung: PT Alumni, 2011), hlm. 86. hIm. 286.

9 Sofyan Safri, Manajemen Kontemporen, (Jakarta: Pt Raja Grafindo Persada, 1996),

${ }^{10}$ Opcit, hlm. 108.
} 
transparan, akuntabel, partisipatif serta dilakukan dengan tertib dan disiplin anggaran. Pengelolaan keuangan desa dikelola dalam masa 1 (satu) tahun anggaran yakni mulai tanggal 1 Januari sampai dengan tanggal 31 Desember. Anggaran Pendapatan dan Belanja Desa, selanjutnya disingkat APBDesa adalah rencana keuangan tahunan pemerintahan desa yang dibahas dan disetujui bersama oleh pemerintah desa dan Badan Permusyawaratan Desa, dan ditetapkan dengan peraturan desa. Bendahara adalah perangkat desa yang ditunjuk oleh Kepala Desa untuk menerima, menyimpan, menyetorkan, menatausahakan, membayarkan dan mempertanggungjawabkan keuangan desa dalam rangka pelaksanaan APBDesa (Permendagri No. 37 Tahun 2007). ${ }^{11}$

Sumber - sumber pendapatan Desa terdiri dari :

a. Pendapatan asli Desa sendiri yang terdiri dari :

1) Hasil tanah-tanah Kas Desa.

2) Hasil dari Swadaya dan Partisipasi masyarakat Desa.

3) Hasil dari gotong royong masyarakat.

4) Lain-lain hasil dari Usaha Desa yang Sah. ${ }^{12}$

b. Pendapatan yang berasal dari Pemberian Pemerintah dan Pemerintah Daerah yang terdiri dari :

1) Sumbangan dan bantuan Pemerintah.

2) Sumbangan dan bantuan Pemerintah Daerah.

3) Sebagian dari Pajak dan retribusi Daerah yang di berikan Kepala Desa.

c. Lain-lain Pendapatan yang sah

Dalam Pengurusan Keuangan Desa, Pemerintah Desa berkewajiban untuk melakukan pencatatan secara teratur menurut tertib waktu dalam Buku Administrasi Keungan Desa, oleh Bendaharawan Desa.

Empat prioritas utama penggunaan dana desa, antara lain sebagai berikut :

a. Pemenuhan kebutuhan dasar

Dalam rangka pemenuhan kebutuhan dasar, maka prioritas penggunaan Dana Desa yaitu; pengembangan pos kesehatan Desa dan Polindes, pengelolaan dan pembinaan Posyandu, pembinaan dan pengelolaan pendidikan anak usia dini.

b. Pembangunan sarana dan prasarana desa

Penggunaan Dana Desa untuk prioritas penggunaan Sarana dan Prasarana Desa harus mendukung target pembangunan sektor unggulan, yang tertuang dalam Rencana Pembangunan Jangka Menengah Nasional (RPJMN) 2015-2019 dan Rencana Kerja Pemerintah (RKP) setiap tahunnya, yang diprioritaskan.

c. Pengembangan potensi ekonomi local

d. Target yang diproritaskan yaitu mendukung kedaulatan pangan, mendukung kedaulatan energi, mendukung pembangunan kemaritiman dan kelautan; dan mendukung pariwisata dan industri. Untuk sarana dan prasarana didasarkan atas kondisi dan potensi Desa, yang sejalan dengan pencapaian target dalam RPJM Desa dan RKPDesa setiap tahunnya.

Dana Desa untuk Pembangunan Sarana dan Prasarana antara lain; pembangunan dan pemeliharaan jalan Desa, pembangunan dan pemeliharaan jalan usaha tani, pembangunan dan pemeliharaan embung Desa, pembangunan energi baru dan terbarukan, pembangunan dan pemeliharaan sanitasi lingkungan.

e. Pemanfaatan sumber daya alam dan lingkungan berkelanjutan

${ }^{11}$ Syahril Mahmud, Administrasi Kas Pendaharawan Pusat, Daerah dan Desa, (Jakarta: Armas Duta Jaya, 1998), hlm. 488.

12 Ibid, hlm. 485. 
Pembangunan dan pengelolaan air bersih berskala Desa, pembangunan dan pemeliharaan irigasi tersier, pembangunan dan pemeliharaan serta pengelolaan saluran untuk budidaya perikanan, dan pengembangan sarana dan prasarana produksi di Desa. Penggunaan Dana Desa juga harus diprioritaskan untuk pemberdayaan masyarakat Desa terutama untuk penanggulangan kemiskinan dan peningkatan akses atas sumber daya ekonomi.

\section{Pembahasan}

1. Penggunaan Dana Desa Sebagai Infrastruktur

Infrastruktur adalah fasilitas-fasilitas fisik yang dikembangkan atau dibutuhkan oleh agen-agen public untuk fungsi-fungsi pemerintah dalam penyediaan air, tenaga, listrik, pembuangan limbah, transportasi dan pelayanan. Berdasarkan hasil observasi awal peneliti bahwa penggunaan infrastruktur di Desa Sijungkang sebesar 70\% yang terdiri dari Rabat beton 20\%, Pergudangan 20\% dan Irigasi 30\% berjalan dengan efekti. Hal ini diperkuat dengan hasil wawancara dengan Bapak Kari Usman Kepdes di Desa Sijungkang mengatakan bahwa: "pembangunan infrasruktur di Desa Sijungkang berjalan dengan efektif ". 13

Keberhasilan penggunaan dana desa sebagai infrastruktur dapat diukur 4 indikator yaitu transparan, akuntabel,partisipatif, tertib dan disiplin anggaran

a. Transparan

Transparan adalah prinsip keterbukaan yang memungkinkan masyarakat untuk mengetahui dan mendapat akses informasi seluas-luasnya tentang keuangan desa. Berdasarkan hasil wawancara yang dilakukan peneliti dan jawaban mereka berbeda ada yang menyatakan bahwa aparat desa terbuka dan tidak terbuka dalam masalah dana desa di Desa Sijungkang.

Hasil wawancara dengan ibu hayani mengatakan bahwa : "aparat desa tidak terbuka dengan masalah keuangan desa mengenai berupa dana desa yang diterima oleh desa dan berapa dsns untuk jumlah pembangunan yang telah dibangun seperti jalan setapak dan tali air kepada masayarakat, Karena aparat desa hanya mengundang yang terkait dengan kepengurusan desa". ${ }^{14}$

Hasil wawancara dengan bapak Ali Aman mengatakan bahwa: "aparat desa terbuka dengan masalah keuangan desa kepada masyarakat mengenai berapa dana desa yang diterima oleh desa dan dana mengenai yang dibangun seperti jalan setapak, dan tali air.karena bapak Ali Aman ikut serta dalam musyawarah desa mengenai dana desa tersebut". 15

Hasil wawancara dengan ibu Risda mengatakan bahwa: "aparat desa tidak terbuka dengan masalah keuangan desa, karena hanya orang-orang yang ikut dalam musyawarah desa yang mengetahuinya, bagi yang tidak ikut dalam musyawarah desa tidak mengetahui dana tersebut". ${ }^{16}$

Berdasarkan hasil observasi lapangan dan wawancara peneliti menyimpulkan bahwa penggunaan dana infrastruktur di desa Sijungkang dapat dikatakan efektif. Hasil observasi peneliti bahwa masalah pencairan dana desa di desa Sijungkang bertahap tergantung pada kebutuhan, Pencairan dana desa terjadi pada dua tahap yakni pada tahap pertama Rp. 463.898.400 dan tahap kedua Rp. 336.101.600. Masalah mengenai

\footnotetext{
${ }^{13}$ Kari Usman, Kepdes Desa Sijungkang, Wawancara Langsung, Tanggal 20 Mei 2018

${ }_{15}^{14}$ Ibu Hayani, masyarakat Desa Sijungkang, wawancara langsung, Tanggal 21 Mei 2018

${ }_{15}^{15}$ Ali Aman, Masyarakat Desa Sijungkang, wawancara langsung, Tanggal 21 Mei 2018

${ }^{16}$ Risda, masyarakat desa sijungkang, wawancara langsung, Tanggal 21 Mei 2018
} 
RAB hanya bendahara desa dan kepala desa tidak ada tim independen lainnya. Hasil observasi peneliti mengenai rekrut tenaga kerja, hanya masyarakat di desa Sijungkang yang mengerjakan pembangunannya seperti jalan setapak dan irigasi.

b. Akuntabel

Akuntabel adalah bahwa setiap tindakan kinerja atau pemerintah/ lembaga dapat dipertanggungjawabkan kepada pihak-pihak yang memiliki hak atau kewenangan untuk meminta keterangan akan pertanggungjawaban. Berdasarkan hasil wawancara yang dilakukan peneliti dan jawaban mereka sama bahwa mereka menyatakan aparat desa membuat buku pertanggungjawabkan tentang dana desa di Desa Sijungkang.

Hasil wawancara dengan kepala desa Kari Usman mengatakan bahwa : "Aparat desa membuat buku pertanggungjawaban mengenai yang dibangun oleh desa seperti jalan setapak dan tali air mulai dari proses perencanaan hingga pertanggungjawaban dan melaporkan APBDesa secara tertib, kepada masyarakat maupun kepada jajaran pemerintahan diatasnya". ${ }^{17}$

Hasil wawancara dengan bendahara desa bapak Hamonangan Harahap menyatakan bahwa : "aparat desa membuat buku pertanggungjawaban kepada masyarakatmaupun kepada jajaran pemerintahan diatasnya mengenai yang dibangun seperti jalan setapak dan tali air ". ${ }^{18}$ Hasil wawancara dengan ibu hayani menyatakan bahwa : "semua pertanggungjawaban dana desa tidak diperlihatkan kepada masyarakat di desa Sijungkang". 19

c. Partisipatif

Partisipatif adalah bahwa setiap tindakan yang dilakukan harus mengikutsertakan keterlibatan masyarakat baik secara langsung maupun tidak langsung. Berdasarkan hasil wawancara yang dilakukan peneliti dan jawabannyasama bahwa masyarakat diikutsertakan dalam pengelolaan keuangan desa di desa Sijungkang.

Hasil wawancara dengan kepala desa bapak Kari Usman menyatakan bahwa : "pengelolaan dana desa mengikutsertakan masyarakat karena adanya pelibatan masyarakat, semua dana desa dapat ditetapkan berdasarkan kebutuhan masyarakat". ${ }^{20}$ Pembangunan jalan setapak dan tali air bahwa masyarakat desa sijungkang yang mengerjakannya sendiri.

Hasil wawancara dengan BPD Saripuddin Harahap menyatakan bahwa : masyarakat diikutsertakan dalam pengelolaan dana desa karena adanya pelibatan masyarakat semua dana desa dapat ditetapakan berdasarkan kebutuhan masyarakat. ${ }^{21}$ Hasil wawancara dengan masyarakat ibu Hayani menyatakan bahwa : "pengelolaan dana desa masyarakat diikutsertakan dalam pembangunannya seperti jalan setapak dan tali air, karena pembangunan berdasarkan dari masyarakat itu sendiri dan bentuk apresiasi dari masyarakat. ${ }^{22}$

d. Tertib dan Disiplin Anggaran

Tertib dan Disiplin Anggaran adalah seluruh anggaran harus dilaksanakan secara konsisten dan dilakukan percatatan atas penggunaannya yang sesuai dengan prinsip akuntansi keuangan desa. Berdasarkan hasil wawancara yang dilakukan peneliti bahwa

${ }^{17}$ Kari Usman, Kepala Desa Sijungkang, wawancara langsung, Tanggal 20 Mei 2018 Mei 2018

${ }^{18}$ Hamonangan Harahap, bendahara desa Sijungkang, wawancara langsung, Tanggal 21

${ }^{19}$ Hayani, masyarakat desa Sijungkang, wawancara Langsung, Tanggal 21 Mei 2018

${ }^{20}$ Kari Usman, kepala desa Sijungkang, wawancara langsung, Tanggal 20 Mei 2018

${ }^{21}$ Saripuddin Harahap, BPD desa Sijungkang, wawancara langsung, Tanggal 23 Mei 2018

22 Hayani, masyarakat desa Sijungkang, wawancara langsung, Tanggal 21 Mei 2018 
Tertib dan Disiplin Anggaran samapendapat antara masyarakat dengan aparat desa. Hasil wawancara dengan kepala desa Sijungkang Kariusman Hasibuan menyatakan bahwa : "seluruh anggaran terlaksanakan secara konsisten dan dilakukan sesuai dengan prinsip akuntansi keuangan desa". ${ }^{23}$ Dalam pembangunan jalan setapak dan tali air semuanya terlaksana dengan baik dan konsisten. Hasil wawancara dengan Bendahara Desa Hamonangan menyatakan bahwa : "seluruh anggaran desa terlaksana dengan baik sesuai dengan akuntansi keuangan desa". 24

2. Faktor Pendukung dan Penghambat dalam Pengelolaan Keuangan Desa

a. Faktor pendukung

Faktor pendukung dalam pengelolaan keuangan desa salah satunya adalah partisipasi masyarakat. Dari hasil penelitian dan pengamatan yang telah dilakukan pada desa Sijungkang, bahwa tingkat partisipasi masyarakat dalam proses perencanaan sampai pada pelaksannaan dalam pengelolaan cukup tinggi. Hasil penelitian ini menunjukkan tingginya tingkat partisipasi masyarakat dalam musyawarah desa dapat dilihat dari tingkat kehadiran dan jumlah usulan oleh masyarakat cukup tinggi. Tingginya partisipasi masyarakat dalam pengelolaan keuangan desa pada desa Sijungkang sesuai dengan teori pemberdayaan menurut Wahyujudin yang menjelaskan bahwa perberdayaan dapat berupa ide dan gagasan dalam forum atau diskusi secara bebas dan tanpa tekanan.

Berdasarkan hasil penelitian dan pengamatan yang telah dilakukan, budaya gotong royong masyarakat merupakan salah satu faktor pendukung dalam pengelolaan keuangan desa di desa Sijungkang. Budaya gotong royong masyarakat yang tinggi dapat mendukung pengelolaan keuangan desa khususnya pada tahap pelaksanaan kegiatan.

b. Faktor penghambat

Selain adanya faktor pendukung mengenai pengelolaan keuangan desa, tentu saja terdapat faktor penghambat didalamnya, berdasarkan sumber yang diperoleh terdapat beberapa faktor penghambat yaitu:

a. Faktor Sumber Daya Manusia (SDM)

Sumber daya manusia dari penduduk desa yang rendah dilihat dari tingkat pendidikan mayoritas penduduk lulusan SD sedangkan perangkat desa sendiri ratarata lulusan SMP. Hal tersebut berdampak pada kegiatan pengelolaan pada tahap perencanaan. Pada proses musyawarah desa terlihat bahwa partisipasi masyarakat tinggi, namun bentuk - bentuk usulan kegiatan dari masyarakat cenderung bersifat pembangunan fisik seperti pembangunan jalan setapak, irigasi, dan lainnya. Padahal kegiatan tersebut tidak bersifat pemberdayaan pada diri masyarakat sendiri. Sehingga pola pikir masyarakat dalam perencanaan penggunaan keuangan desa tersebut merupakan cerminan dari rendahnya tingkat pendidikan masyarakat dan perangkat desa, sehingga belum ada bentuk kreativitas dan inovasi dalam pengelolaan keuangan desa untuk pemberdayaan masyarakat.

b. Faktor cuaca

Cuaca hujan cukup membuat kerjaan menjadi tersendat seperti yang dikatakan Kepala Desa Sijungkang Bapak Kari Usman“cuaca menjadi salah satu hambatan di desa Sijungkang yaitu seperti hujan, karena pada saat terjadinya proses

\footnotetext{
${ }^{23}$ Kariusman Hasibuan, Kepala Desa Sijungkang, wawancara langsung, Tanggal $20 \mathrm{Mei}$ 2018

${ }^{24}$ Hamonangan, Bendahara Desa, wawancara Langsung, Tanggal 21 Mei 2018
} 
pembangunan, pembangunan tidak bisa dilanjutkan. Apabila pembangunan dilanjutkan bangunan yang dibangun akan cepat rusak." 25

\section{Penutup}

Berdasarkan hasil penelitian yang telah dilakukan oleh peneliti terhadap efektivitas pengelolaan keuangan desa sebagai pemberdayaan masyarakat di Desa Sijungkang Kecamatan Angkola Timur Kabupaten Tapanuli Selatan, maka dapat disimpulkan sebagai berikut:

1. Penggunaan dana desa sebagai infrastruktur di Desa Sijungkang Kecamatan Angkola Timur Kabupaten Tapanuli Selatan. Sudah sesuai dengan program namun penyesuaian dana desa belum efektif dimana menejemen merupakan indikator transpransi sehingga masyarakat tidak mengetahui secara menyeluruh.

2. Faktor pendukung pengelolaan dana desa adalah partisipasi masyarakat dalam proses pembangunan desa yang ada di desa sijungkang dan faktor penghambat dalam pengelolaan keuangan desa di Desa Sijungkang yakni faktor sumber daya manusia dan faktor cuaca.

\section{DAFTAR PUSTAKA}

Dianto, Icol. "PEMBERDAYAAN KELOMPOK USAHA PENINGKATAN PENDAPATAN KELUARGA SEJAHTERA (UPPKS) DALAM MENINGKATKAN KESEJAHTERAAN KELUARGA DI PASAMAN.” Jurnal Hikmah 10, no. 1 (2016): 122.

\section{_ "PERANAN DAKWAH DALAM PROSES PENGEMBANGAN}

MASYARAKAT ISLAM.” Jurnal Hikmah 12, no. 1 (2018): 93.

Hurairah, Abu. Pengorganisasian Dan Pengembangan Masyarakat. Bandung: Humaniora, 2011.

Abu Ahmadi,Ilmu Sosial Dasar, Jakarta : Rineka Cipta, 2009

Adi Satrjo, Kamus Ilmiah Populer Bandung : Visi 7, 2005

Ahmad Nizar Rangkuti, Metode Penelitian Pendidikan Pendekatan Kwalitatif PTK dan Penelitian Pengembangan, Bandung: CitaPustaka Media, 2016

Cholid Nurbuko Dan Abu Ahmadi, Metodologi Penelitian Jakarta : PT Bumi Aksara, 2005

Hartomo Dan Arnicun, Ilmu Sosial Dasar, Jakarta : BumiAksara, 1990

Hasan Shadily, Sosiologi Untuk Masyarakat Indonesia, Jakarta : PT Pembangunan, 1995

http://wwwliteraturbook.blogspot.co.id/2014/12/pengertian-efektivitas-dan-landasan.html di aksesspadatanggal 15 maret 2018

http://www.akuntansilengkap.com/ekonomi/pengertian-dan-contoh-kebutuhan-primer-sekunder-dantersier/ di aksespadatanggal 15 maret 2018

Ibnu Hasan Muchtar Dan Farhan Muntafa, Efektivitas FKUB Dalam Pemeliharaan Kerukunan Umat Beragama Jakarta : Puslitbang Kehidupan Keagamaan, 2015

Joko Tri Prasetya, Ilmu Budaya Dasar, Jakarta :Rineka Cipta, 2011

\footnotetext{
${ }^{25}$ Kari Usman, Kepala Desa Sijungkang, wawancara langsung Tanggal 20 mei 2018
} 
Kementerian Koordinator Bidang Pembangunan Manusia dan Kebudayaan Republik Indonesia, Pedoman Umum (Pedum) Raskin 2016 Bab II Tujuan, Sasaran Dan Manfaat Raskin

Kementerian Koordinator Bidang Pembangunan Manusia dan Kebudayaan Republik Indonesia, Pedoman Umum (Pedum) Raskin 2014 Bab I

LexyJ.Moloeng, MetodologiPenelitianKualitatifBandung :RemajaRosdakarya, 2000

Mohammad Nazir, Metode Penelitian Jakarta : Ghalia Indonesia, 2005

Muhammad Zid Dan Ahmad Tarmiji Alkhudri, Sosiologi Pedeseaan Teoretisasi Dan Perkembangan Kajian Pedesaan Di Indonesia, Jakarta : PT Raja Grafindo Persada, 2016

Muh.Syarifuddin, “Analisis Tentang Aktivitas Buruh Tani dalam Memenuhi Kebutuhan Pokok di Kelurahan Bukuan Kecamatan Palaran Kota Samarinda" Ejournal Sosiatri-Sosiologi Vol. 4, No. 3, 2016

Munandar Soelaeman, Ilmu Social Dasar :Teori Dan Konsep Ilmu Sosial , Edisi Revisi, Bandung : Eresco, 1989

M. Munandar Soelaeman ,Ilmu Sosial Dasar : Teori Dan Konsep Ilmu Sosial, Bandung : Ersco , 1993

Ombi Romli," Implementasi Program Beras Miskin (Raskin) di Desa Sakti Kecamatan Kabupaten Pandeglang"Jurnal Kapenda- Kajian Administrasi dan Pemerintah vol 10, no. 6, maret 2017

Pembukaan Undang-Undang Dasar 1945 Dan Batang Tubuh, Pasal 33 Ayat (3) Dan 34

Racmat Kriyantono, Teknik Praktis Riset Komunikasi Jakarta : Kencana, 2008

Sukardi, MetodePenelitianPendidikan Jakarta : PT BumiAksara, 2000

Soewarno Handayaningrat, Sistem birokrasi Pemerintahan, Jakarta: PT Raja Grafindo Persada, 1985

Syarul Ramadhan, KamusIlmiah Popular, Surabaya :Khanzanah Media Ilmu, 2010

T. Hani Handoko, Manajemen, Yogyakarta: BPFE, 2003

Wibowo, Manajemen Kinerja Jakarta : PT Persada Granfindo Persada, 2012. 